\title{
EFFECT OF RUMEN PROTECTED METHIONINE SUPPLEMENTATION ON EARLY LACTATIONAL RESPONSES OF DAIRY COWS FED A GRASS SILAGE AND CEREALS DIET
}

\author{
Stefania IwAŃSKA, Danuta STRUSIŃSKA and Barbara PYSERA \\ Institute of Animal Nutrition and Feed Management, University of Agriculture and \\ Technology, 10-718 Olsztyn-Kortowo, Poland
}

(Received April 10, 1998; accepted September 25, 1998)

\begin{abstract}
To investigate the milk production limiting potential of a diet based on grass silage (40\%), hay (15\%), dried sugar beet pulp (13\%) and grain compound mixture (32\%), 28 multiparous cows in early lactation were randomly assigned to two treatment groups: a control group and a group receiving supplementary rumen protected methionine (RPMet) treatment (12 g intestinally available methionine/ cow/day, given 1-120 days postpartum; Smartamine ${ }^{\text {TM}}$; RPAN's technology). The diet was formulated to meet the requirements for protein and net energy. RPMet supplementation had no significant effect on DMI (kg/cow/day), milk dry mass, milk lactose and milk urea contents. Responses for mean daily milk yield, mean milk fat and milk protein yields were significantly higher $(\mathrm{P}<0.05)$ in cows supplied with RPMet than in controls. Mean daily milk yield, milk protein and milk fat yields increased by $2.4 \mathrm{~kg}, 108 \mathrm{~g}$ and $124 \mathrm{~g}$, respectively. The mean daily milk protein and casein contents were increased by $1.8 \mathrm{~g}$ and $0.9 \mathrm{~g}$ and milk fat content by $1.2 \mathrm{~g}$ in $1 \mathrm{~kg}$ of milk, respectively. The results suggest that in cows fed grass silage and a grain compound mixture milk production is limited by methionine insufficiency, but milk production performance can be increased significantly by the addition of RPMet to the diet.
\end{abstract}

Key words: Rumen protected methionine, milk yield, milk protein, milk fat, early lactation, dairy cow

The protein nutrition of dairy cows has been studied extensively in terms of response to different levels and sources of crude protein in the diet (Bruckental et al., 1989; McCarthy et al., 1989; Broderick, 1992; Metcalf et al., 1996), but individual amino acid requirements for different stages of lactation have not been determined.

The amino acid requirement is significantly affected by the rumen degradability of dietary crude protein. The differences in degradation of crude protein from forages and concentrates and the dynamics of microbial protein synthesis in the rumen have made it difficult to significantly alter the ratio and the quantity of amino acids reaching the small intestine (King et al., 1990; Sey- 
mour et al., 1990; Schwab et al., 1992a, Schwab et al., 1992b). Previous studies support the hypothesis that the principal sources of variation in the amino acid balance of intestinal digesta are the amino acid composition of feed proteins and the proportional flow of ruminally undegraded intake protein and microbial protein to the intestines (Rulquin et al., 1993; Rulquin et al., 1995). Attempts to increase the passage of essential amino acids to the intestines by feeding protein sources with low rumen degradabilities had variable success (McCarthy et al., 1989; Seymour et al., 1990; Broderick, 1992). Although it still is not common to consider individual amino acids when formulating diets for lactating cows, there is increasing evidence that the addition of certain amino acids can improve milk production and particularly milk protein content. Two amino acids, methionine and lysine, are of special interest for dairy cows as they have been identified as the most limiting amino acids for the synthesis of milk protein (Schwab et al., 1992a; Schwab et al., 1992b; Rulquin et al., 1993; Guinard and Rulquin, 1995; Rulquin et al., 1995). Unfortunately, free crystalline methionine is easily and rapidly degraded by rumen bacteria and a variety of approaches have been used to achieve delivery of methionine to absorption sites. Protection of methionine has been attempted by formation of amino acid analogues or derivatives (Chandler et al., 1976; van Hellemond and Sprietsma, 1977; Huber et al., 1984; Lundquist et al., 1985; Patterson and Kung, 1988) or by encapsulation (Papas et al., 1984a; Papas et al., 1984b; Ward et al., 1988; Overton et al., 1996).

It has been suggested that methionine hydroxy analogues might alter ruminal digestion by stimulating the activity of rumen microorganisms, thus causing a shift in rumen fermentation products and an increase in milk fat production with little or no change in milk protein production (van Hellemond and Sprietsma, 1977; Huber et al., 1984; Lundquist et al., 1985; Patterson and Kung, 1988). In the encapsulative method polymeric coatings perfectly protect methionine, as are designed to maintain their structural integrity over the normal range of ruminal $\mathrm{pH}$, but at the lower $\mathrm{pH}$ of the abomasum methionine is released before being absorbed in the small intestine.

Although methionine supplemented in this protected form has failed to improve milk yield and milk protein content (Armentano et al., 1993), the response to protected methionine feeding was variable and mainly depended on protein source and level in the basal diet (Polan et al., 1991; Schwab et al., 1992a; Schwab et al., 1992b; Rulquin et al., 1993; Colin-Schoellen et al., 1995; Rulquin et al., 1995; Sloan and Robert, 1995; Armentano et al., 1997; Wu-Z et al., 1997). The inconsistency of responses to supplemental protected methionine may indicate that methionine is not always the first-limiting amino acid.

However, in grass forage based diets supplemented with grain concentrates methionine has been found to be the principal limiting amino acid (Rogers et al., 1979; Thomas et al., 1980a; Chamberlain and Thomas, 1982; Robert et al., 
1994; Rulquin et al., 1995). If methionine is the most limiting substrate for milk yield and milk component synthesis of early-lactation cows fed a diet based on grass silage and cereals, then increased delivery of protected methionine in an encapsulated form should increase milk production.

In this study, the diet of early-lactation cows, consisting of grass silage and a grain compound mixture, was supplemented with rumen protected methionine (Smartamine ${ }^{\mathrm{TM}}$ ) in order to study the effects of this supplementation on the milk yield and the production of milk components, as well as on the concentrations of some constituents of blood serum and milk.

\section{Material and methods}

\section{Animals, feeding and treatments}

The studies were carried out on multiparous Black-and-White cows assigned randomly to two groups: control and experimental (14 cows in each) on the basis of genetic indices and similarity of the previous year's lactation performance $(4400 \mathrm{~kg})$, content of milk components, number of previous lactations (4-6), period of pregnancy, age, body weight, and health status. All animals were healthy throughout the experiment and no medical treatments were given.

The cows were housed in a tie-stall barn and received a common, basal diet formulated to meet nutrient requirements for corresponding body weight, milk production and milk composition. The daily ration consisted of wilted grass silage $(18 \mathrm{~kg})$, hay $(3 \mathrm{~kg})$, dried sugar beet pulp $(1 \mathrm{~kg})$, and compound mixture $(3 \mathrm{~kg})$. Cows producing more than $14 \mathrm{~kg}$ of milk daily received an additional $0.3 \mathrm{~kg}$ of compound mixture and $0.25 \mathrm{~kg}$ of dried sugar beet pulp per each $1 \mathrm{~kg}$ of milk produced in excess of $14 \mathrm{~kg}$. The diet (DM) consisted of $55 \%$ forage and $45 \%$ concentrate. Forage was given for ad libitum intake, twice daily. The compound mixture was fed individually four times and dried sugar beet pulp twice daily. Water was always available. The ingredients and chemical composition of the ration are shown in Table 1.

The treatments consisted of a control group and a group receiving supplementary methionine treatment in the form of Smartamine ${ }^{\mathrm{TM}}$ produced by Rhône Poulenc (France). Each beadlet of Smartamine ${ }^{\mathrm{TM}}$ contained a core of concentrated $(>75 \%)$ methionine, protected in the rumen by a $\mathrm{pH}$-sensitive coating, released in the abomasum before being absorbed in the small intestine. Supplementation with rumen protected methionine was started on the day of calving and was continued over 120 days of the lactation. The supplement of Smartamine ${ }^{\mathrm{TM}}$ (12 g/day/cow) was mixed with the compound mixture every day and fed individually with morning ration. 
Table 1

Ingredients, chemical composition and nutritive value of the diet (DM basis)

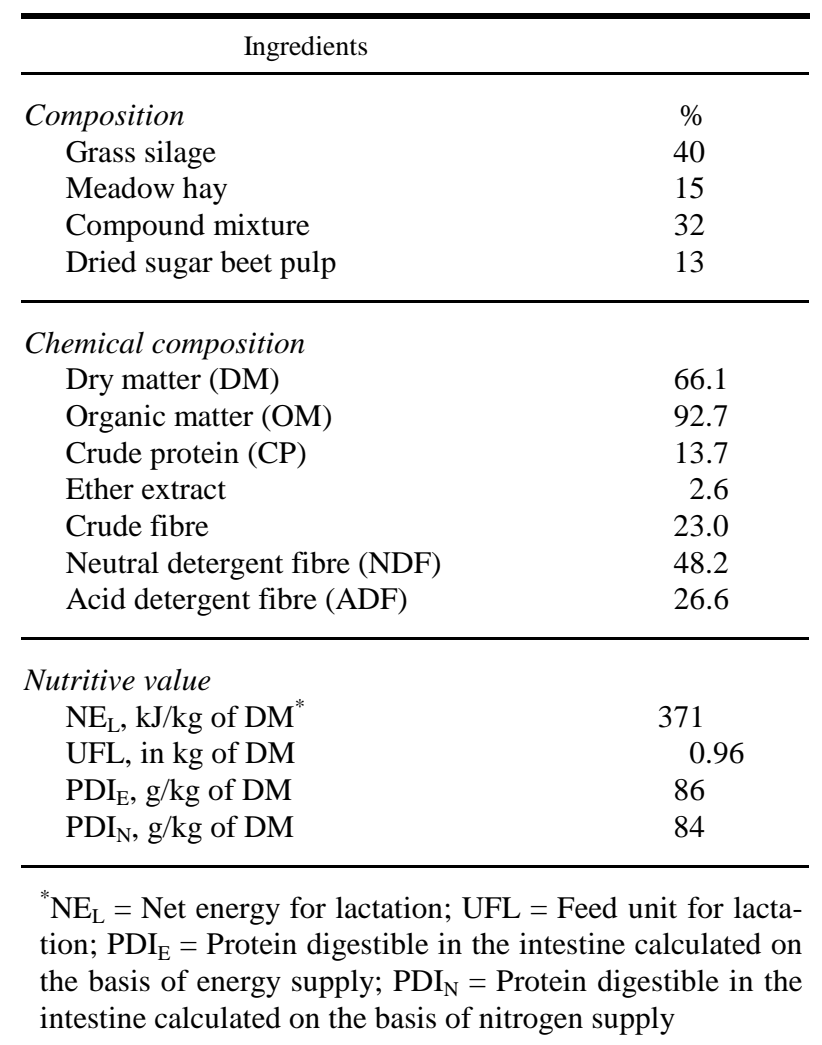

\section{Sample collection and analytical procedures}

Feed samples of daily diet ingredients were collected bimonthly, composited monthly and analysed for absolute dry mass, crude protein and crude ash (AOAC, 1984) for crude fibre and ether extract (Skulmowski, 1974). The ADF and NDF fractions, as well as cellulose and hemicellulose of crude fibre, were determined according to Van Soest and Wine (1967).

Cows were milked twice daily. The experimental period comprised the following sequence: for all cows between Day 1 and Day 120 of lactation daily milk yield was recorded individually, weighed and sampled at both milkings on the same 3 consecutive days of each week. As a result, milk yield and milk components were measured on 51 days during the 120-day period. The mean values of these measurements served as covariates in the statistical analysis of corresponding measurements made during treatment. 
Milk samples were analysed for dry mass, non-fat solids, milk fat, milk protein and milk lactose by Milko Scan 133B (Foss Electric). Milk casein content was estimated by the formalin method of Wocker (Budsławski, 1979). Milk urea nitrogen was analysed in deproteinized milk using a colorimetric diacetyl monoxine procedure (No. 535; Sigma Diagnostics, St. Louis, MO) and spectrophotometry with absorbance at $535 \mathrm{~nm}$.

Jugular vein blood samples were taken prior to the morning feeding 2 weeks before calving and on Days 7, 56 and 100 of lactation. Serum samples were analysed for total protein, blood urea nitrogen (BUN), and glucose content using the tests of Alpha Diagnostic Methods and an Epoll 20 spectrophotometer.

The determination of individual amino acids in feeds and blood plasma was performed using a Model 6300 high-performance analyser (Beckman, USA). Vacuum-dried hydrolysates of feed samples and deproteinized blood plasma (both taken in two replications) were diluted to a concentration of $0.2 \mathrm{M}$ with sodium citrate buffer and the method of buffers A, B, D was used for the separation of individual amino acids.

Statistical evaluation of the results was carried out by analysis of variance, followed by least significant difference calculated by Duncan's multiple range tests (Backsalary et al., 1977).

\section{Results}

The analysis of chemical composition and concentration of nutrients supplied in dry mass of daily diet showed that the overall intakes of some nutrients were slightly higher than the requirements (Jarrige, 1989) and the ration was estimated to account approximately for 110, 104 and 101.5\% of total energy, crude protein and protein digestible in the intestine calculated on the basis of nitrogen supply $\left(\mathrm{PDI}_{\mathrm{N}}\right)$ requirements, respectively (Tables 1 and 2 ). The diet was formulated not only to meet crude protein, protein digestible in the intestine, calculated on the basis of energy $\left(\mathrm{PDI}_{\mathrm{E}}\right)$, and nitrogen supply $\mathrm{PDI}_{\mathrm{N}}$ requirements, but also in relation to methionine requirement. The estimated profiles of amino acids in feed components of the diet (Table 3) are comparable with the concentration of amino acids estimated in feeds by others (Ryś, 1985). However, from the content of methionine digestible in the intestine (MetDI), expressed as per cent of protein digestible in the intestine (PDI) (Table 2), it is evident that the daily ration provided only $24.3 \mathrm{~g}$ MetDI and that the diet met only $72 \%$ of the methionine requirement. The additional amount of rumen protected methionine (RPMet) supplied in the form of Smartamine ${ }^{\mathrm{TM}}$ (75\% of DL-methionine) provided an additional $9 \mathrm{~g}$ of RPMet, which made it possible to increase the MetDI concentration to the level thought to be adequate for meeting the requirements of by dairy cows producing 20-22 $\mathrm{kg}$ of milk daily. 
Table 2

Feed intake and nutrient supply

\begin{tabular}{|c|c|}
\hline Measurement & $\mathrm{kg}$ \\
\hline \multicolumn{2}{|l|}{ Intake of $\mathrm{kg} D M /$ day } \\
\hline Grass silage & 6.5 \\
\hline Meadow hay & 2.5 \\
\hline Compound mixture & 5.3 \\
\hline Dried sugar beet pulp & 2.1 \\
\hline Total & 16.4 \\
\hline \multicolumn{2}{|l|}{ Nutrient supply } \\
\hline $\mathrm{NE}_{\mathrm{L}}, \mathrm{kJ}$ & 6089 \\
\hline UFL & 15.6 \\
\hline $\mathrm{CP}, \mathrm{g} / \mathrm{d}$ & 2248 \\
\hline $\mathrm{PDI}_{\mathrm{E}}, \mathrm{g} / \mathrm{d}$ & 1406 \\
\hline $\mathrm{PDI}_{\mathrm{N}}, \mathrm{g} / \mathrm{d}$ & 1375 \\
\hline Met, g/kg PDI* & 24.6 \\
\hline
\end{tabular}

${ }^{*}$ MetPDI $=$ methionine of protein digestible in the intestine

Table 3

Amino acid content of feeds $(\mathrm{g} / 16 \mathrm{~g} \mathrm{~N})$

\begin{tabular}{lcccc}
\hline \multirow{2}{*}{ Amino acids } & \multicolumn{3}{c}{ Feeds } \\
\cline { 2 - 5 } & Grass silage & Meadow hay & Compound mixture & Dried sugar beet pulp \\
\hline Lys & 3.60 & 5.21 & 5.60 & 5.57 \\
Met & 0.86 & 1.02 & 2.06 & 0.89 \\
Thr & 2.05 & 3.31 & 3.63 & 4.20 \\
Arg & 2.05 & 3.59 & 5.29 & 3.36 \\
Phe & 2.35 & 3.99 & 4.56 & 2.99 \\
His & 1.63 & 2.54 & 2.92 & 3.77 \\
Ile & 2.34 & 3.44 & 3.89 & 3.42 \\
Leu & 3.81 & 5.82 & 6.54 & 5.24 \\
Val & 3.09 & 4.37 & 5.35 & 6.05 \\
Cys & 0.57 & 0.51 & 2.08 & 0.50 \\
Tyr & 1.78 & 3.47 & 3.43 & 4.16 \\
Ala & 3.48 & 4.59 & 4.36 & 4.27 \\
Gly & 2.65 & 4.22 & 4.65 & 4.08 \\
Asp & 4.81 & 8.50 & 7.55 & 7.36 \\
Glu & 6.45 & 9.92 & 18.82 & 9.61 \\
Pro & 3.21 & 5.28 & 6.86 & 4.31 \\
Ser & 1.88 & 3.09 & 3.83 & 3.99 \\
\hline
\end{tabular}


Supplementation with RPMet significantly affected the milk yield, the $4 \%$ fat corrected milk yield ( $4 \%$ FCM) and milk composition. The increase of mean daily milk production $(\mathrm{kg} / \mathrm{d})$ for the RPMet group was significant as compared to the control (21.2 vs. 18.8; $\mathrm{P}<0.05)$. Responses obtained for mean daily milk yield $(\mathrm{kg} / \mathrm{d})$, mean daily milk fat and mean daily milk protein yields $(\mathrm{g} / \mathrm{d})$ in cows supplied with RPMet were significantly higher $(\mathrm{P}<0.05)$ by $2.4,124$ and 108 , respectively (Table 4). Differences were also found in mean milk protein, casein and fat contents. The mean daily protein and casein contents increased by $1.8 \mathrm{~g}$ and $0.9 \mathrm{~g}$, respectively, and mean daily fat content by $1.2 \mathrm{~g}$ in $1 \mathrm{~kg}$ of milk. The ratio of milk casein content to milk protein content was slightly lower in cows supplied with RPMet (0.79) than in the controls (0.81), indicating that the increase in milk protein was due to a proportional increase in milk casein and in other milk proteins. Although RPMet supplementation influenced milk production throughout the 120 days of lactation, the mean daily milk yield for the studied periods of early lactation was inconsistent and the highest increase was observed from the first 4 weeks through the next 13 weeks of lactation (Table 5).

Table 4

Effect of RPMet on mean daily milk production and milk composition*

\begin{tabular}{|c|c|c|c|c|}
\hline \multirow{3}{*}{ Item } & \multicolumn{4}{|c|}{ Groups of cows } \\
\hline & \multicolumn{2}{|c|}{ Control } & \multicolumn{2}{|c|}{ RPMet } \\
\hline & $\bar{x}$ & $\mathrm{~s}$ & $\bar{x}$ & $\mathrm{~s}$ \\
\hline No. of cows & \multicolumn{2}{|c|}{14} & \multicolumn{2}{|c|}{14} \\
\hline \multicolumn{5}{|l|}{ Yield } \\
\hline Milk, kg/d & $18.8^{\mathrm{a}}$ & 2.4 & $21.2^{\mathrm{b}}$ & 2.8 \\
\hline $4 \% \mathrm{FCM}, \mathrm{kg} / \mathrm{d}$ & $19.2^{\mathrm{a}}$ & & $22.0^{\mathrm{b}}$ & \\
\hline Fat, g/d & $778^{\mathrm{a}}$ & 82 & $902^{\mathrm{b}}$ & 94 \\
\hline Protein, g/d & $548^{\mathrm{a}}$ & 51 & $656^{\mathrm{b}}$ & 42 \\
\hline \multicolumn{5}{|l|}{ Content, g/100 g } \\
\hline Fat & 4.13 & 0.60 & 4.25 & 0.53 \\
\hline Protein & $2.91^{\mathrm{a}}$ & 0.23 & $3.09^{\mathrm{b}}$ & 0.20 \\
\hline Casein & 2.36 & 0.32 & 2.45 & 0.26 \\
\hline Lactose & 4.78 & 0.21 & 4.70 & 0.23 \\
\hline Dry mass & 12.32 & 1.01 & 12.31 & 0.98 \\
\hline Milk non-fat solids & 8.34 & 0.63 & 8.04 & 0.59 \\
\hline Urea, mmol/1 & 2.30 & 0.55 & 2.49 & 0.84 \\
\hline
\end{tabular}

*Mean daily values for Days 1-120 of lactation; s = standard deviation; Significance of differences: $\mathrm{a}, \mathrm{b}=\mathrm{P}<0.05$ 
Table 5

Effect of RPMet on mean daily milk yield and milk composition

\begin{tabular}{|c|c|c|c|c|c|c|c|c|}
\hline \multirow{2}{*}{ Item } & \multirow{2}{*}{$\begin{array}{l}\text { Groups } \\
\text { of cows }\end{array}$} & & \multicolumn{6}{|c|}{ Days of milk sampling } \\
\hline & & & 14 & 28 & 42 & 56 & $57-100$ & $101-120$ \\
\hline \multirow[t]{4}{*}{ Milk yield, $\mathrm{kg} / \mathrm{d}$} & Control & & 22.5 & $20.45^{\mathrm{a}}$ & $20.60^{\mathrm{a}}$ & $20.77^{\mathrm{a}}$ & $18.03^{\mathrm{a}}$ & $16.40^{\mathrm{a}}$ \\
\hline & & $\mathrm{s}$ & 1.71 & 3.39 & 2.21 & 1.64 & 3.31 & 1.09 \\
\hline & RPMet & & 22.65 & $22.18^{\mathrm{b}}$ & $22.38^{\mathrm{b}}$ & $21.78^{\mathrm{b}}$ & $20.34^{\mathrm{b}}$ & $18.40^{\mathrm{b}}$ \\
\hline & & $\mathrm{s}$ & 2.57 & 2.1 & 2.33 & 1.87 & 1.51 & 2.5 \\
\hline \multirow[t]{2}{*}{ Milk 4\% FCM, kg/d } & Control & & 25.26 & $20.70^{\mathrm{a}}$ & $20.94^{\mathrm{a}}$ & $19.71^{\mathrm{a}}$ & $17.92^{\mathrm{a}}$ & $17.14^{\mathrm{a}}$ \\
\hline & RPMet & & 25.16 & $22.61^{\mathrm{b}}$ & $23.05^{\mathrm{b}}$ & $22.07^{\mathrm{b}}$ & $20.34^{\mathrm{b}}$ & $19.25^{\mathrm{b}}$ \\
\hline \multirow[t]{4}{*}{ Milk fat, $g / 100 \mathrm{~g}$} & Control & & 4.82 & 4.08 & 4.11 & 3.66 & 3.96 & 4.3 \\
\hline & & $\mathrm{s}$ & 0.47 & 0.28 & 0.94 & 0.29 & 0.33 & 0.47 \\
\hline & RPMet & & 4.74 & 4.13 & 4.2 & 4.09 & 4 & 4.31 \\
\hline & & $\mathrm{s}$ & 0.33 & 0.4 & 0.46 & 0.37 & 0.43 & 0.51 \\
\hline \multirow[t]{4}{*}{ Milk protein, $\mathrm{g} / 100 \mathrm{~g}$} & Control & & $3.15^{\mathrm{a}}$ & 3.02 & 2.73 & $2.77^{\mathrm{a}}$ & 2.84 & $2.88^{\mathrm{a}}$ \\
\hline & & $\mathrm{s}$ & 0.16 & 0.13 & 0.11 & 0.06 & 0.08 & 0.12 \\
\hline & RPMet & & $3.33^{\mathrm{b}}$ & 2.97 & 2.82 & $2.95^{\mathrm{b}}$ & 2.89 & $3.04^{\mathrm{b}}$ \\
\hline & & $\mathrm{s}$ & 0.17 & 0.15 & 0.05 & 0.07 & 0.12 & 0.14 \\
\hline \multirow[t]{4}{*}{ Milk casein, g/100g } & Control & & 2.5 & 2.37 & 2.37 & 2.32 & $2.30^{\mathrm{a}}$ & 2.37 \\
\hline & & $\mathrm{s}$ & 0.13 & 0.11 & 0.09 & 0.1 & 0.14 & 0.12 \\
\hline & RPMet & & 2.54 & 2.46 & 2.4 & 2.38 & $2.43^{\mathrm{b}}$ & 2.44 \\
\hline & & $\mathrm{s}$ & 0.16 & 0.13 & 0.06 & 0.09 & 0.17 & 0.14 \\
\hline
\end{tabular}

Significance of differences: $\mathrm{a}, \mathrm{b}=\mathrm{P}<0.05$ 
RPMet addition had no effect on milk dry mass, milk non-fat solids, and milk lactose (Table 4).

Effects of RPMet supplementation on the concentrations of some blood serum constituents are presented in Table 6 . The energy-yielding metabolite glucose was maintained nearly at the same levels in both groups of cows and significant difference $(\mathrm{P}<0.05)$ in serum glucose content was noticed only at Day 56 of lactation.

The total protein content of the blood serum was relatively constant and not affected significantly by RPMet supplementation. Serum urea contents were very similar in both groups of cows prepartum. After calving the urea content of the blood serum was stable in the control cows, but in the RPMet group the serum urea content tended to increase, and the difference in urea levels was significant at Day 56 of lactation; however, the milk urea output did not increase (Table 6).

\section{Table 6}

Effect of RPMet on some indices of blood serum

\begin{tabular}{|c|c|c|c|c|c|c|}
\hline \multirow{2}{*}{$\begin{array}{c}\text { Groups of } \\
\text { cows }\end{array}$} & \multicolumn{2}{|c|}{$\begin{array}{c}\text { Glucose } \\
\mathrm{mmol} / \mathrm{l}\end{array}$} & \multicolumn{2}{|c|}{$\begin{array}{l}\text { Total protein } \\
\mathrm{g} / 1\end{array}$} & \multicolumn{2}{|c|}{$\begin{array}{l}\text { Urea } \\
\mathrm{mmol} / \mathrm{l}\end{array}$} \\
\hline & $\bar{x}$ & $\mathrm{~s}$ & $\bar{x}$ & $\mathrm{~s}$ & $\bar{x}$ & s \\
\hline & \multicolumn{6}{|c|}{ Days of blood sampling } \\
\hline & \multicolumn{6}{|c|}{14 days prepartum } \\
\hline Control & 3.62 & 1.20 & 77 & 17 & 6.19 & 1.52 \\
\hline \multirow[t]{2}{*}{ RPMet } & 3.39 & 0.93 & 84 & 19 & 6.07 & 1.23 \\
\hline & \multicolumn{6}{|c|}{ On Day 7 of lactation } \\
\hline Control & 2.94 & 0.64 & 82 & 15 & 4.34 & 1.02 \\
\hline \multirow[t]{2}{*}{ RPMet } & 3.03 & 1.02 & 83 & 17 & 5.24 & 1.34 \\
\hline & \multicolumn{6}{|c|}{ On Day 56 of lactation } \\
\hline Control & 2.97 & 0.61 & 82 & 13 & 4.75 & 0.93 \\
\hline \multirow[t]{2}{*}{ RPMet } & 3.74 & 0.84 & 79 & 16 & 5.64 & 1.60 \\
\hline & \multicolumn{6}{|c|}{ On Day 100 of lactation } \\
\hline Control & 2.91 & 0.63 & 86 & 8 & 4.49 & 0.87 \\
\hline RPMet & 2.67 & 0.70 & 93 & 11 & 4.34 & 0.91 \\
\hline
\end{tabular}


It is evident from Table 3 that the amino acid concentration of individual feed components of the daily diet was typical of the ration based on grass silage and grain compound mixture. The results shown in Table 3 suggest that the diet was more adequate in lysine and more deficient in methionine, histidine and cystine. RPMet supplementation affected the concentration of individual amino acids in blood plasma (Table 7). The effect of RPMet was reflected in a significant increase of methionine content (48.3\%) and in an improved status of some other amino acids in the blood plasma. Addition of RPMet improved the blood plasma concentration of isoleucine, lysine and cystine by $18.6 \%, 16.2 \%$ and $6.0 \%$, respectively. An insignificant increase in the serum concentrations of some nonessential amino acids was also observed.

Table 7

Concentration of amino acids in the blood plasma $(\mu \mathrm{mol} / 100 \mathrm{ml})^{*}$

\begin{tabular}{|c|c|c|c|c|}
\hline \multirow{3}{*}{ Amino acids } & \multicolumn{4}{|c|}{ Groups } \\
\hline & \multicolumn{2}{|c|}{ Control } & \multicolumn{2}{|c|}{ RPMet } \\
\hline & $\bar{x}$ & $\mathrm{~s}$ & $\bar{x}$ & $\mathrm{~s}$ \\
\hline Lys & $7.84^{\mathrm{a}}$ & 1.71 & $9.11^{\mathrm{b}}$ & 1.73 \\
\hline Met & $2.46^{\mathrm{A}}$ & 0.21 & $3.66^{\mathrm{B}}$ & 0.31 \\
\hline Thr & 8.29 & 1.43 & 8.55 & 1.31 \\
\hline Arg & 13.21 & 0.66 & 13.82 & 1.25 \\
\hline Phe & 4.80 & 0.36 & 4.43 & 0.81 \\
\hline His & 3.76 & 0.30 & 3.73 & 0.37 \\
\hline Ile & $10.24^{\mathrm{a}}$ & 0.27 & $12.15^{\mathrm{b}}$ & 1.07 \\
\hline Leu & 10.39 & 0.59 & 10.01 & 1.23 \\
\hline Val & 19.44 & 1.71 & 19.24 & 2.49 \\
\hline Cys & 2.94 & 0.39 & 3.13 & 0.73 \\
\hline Tyr & 3.96 & 0.20 & 3.86 & 0.68 \\
\hline Ala & $18.51^{\mathrm{a}}$ & 0.23 & $21.83^{\mathrm{b}}$ & 1.42 \\
\hline Gly & $39.81^{\mathrm{a}}$ & 2.70 & $46.47^{\mathrm{b}}$ & 3.68 \\
\hline Asp & $2.44^{\mathrm{b}}$ & 0.68 & $1.38^{\mathrm{a}}$ & 0.14 \\
\hline Glu & 14.63 & 2.56 & 15.74 & 3.79 \\
\hline Pro & 7.19 & 0.47 & 7.47 & 0.87 \\
\hline Ser & 33.49 & 3.18 & 33.76 & 5.00 \\
\hline
\end{tabular}

*The determination was performed on Day 56 of lactation. Significance of differences: A, B $=\mathrm{P}<$ $0.01 ; \mathrm{a}, \mathrm{b}=\mathrm{P}<0.05$

\section{Discussion}

The results of these studies demonstrated the range of positive responses and indicated the potential for altering lactational performance by RPMet sup- 
plementation corresponding to the nutritional requirement for methionine. The results suggest that methionine was supplied in amounts considered to meet the requirement under the conditions of this experiment, and that the positive responses in milk production were due to an apparent increase in the efficiency of nitrogen utilisation as well as an increased conversion and availability of other nutrients significant for milk synthesis.

The significant increase in milk yield and in the contents and yields of milk components could depend on various nutritional factors other than limited amino acids. The concentration of energy in dry mass of the diet adequately met the requirements for maintenance and recorded milk yields, since blood serum glucose concentrations were generally comparable with levels reported for cows in positive energy balance (Thomas et al., 1980b; Pisulewski et al., 1996).

Although in our studies RPMet supplementation had highly positive effects in terms of milk yield as well as in milk protein and milk fat yields and contents, the published responses elicited by RPMet supplementation in milk and protein yields as well as in milk protein and milk fat content were inconsistent. Encapsulated methionine products fed to lactating cows had no effect on milk yield or milk composition (Papas et al., 1984a; Papas et al., 1984b; Overton et al., 1996), increased only milk protein content and yield (Illg et al., 1987; Casper and Schingoethe, 1988; Donkin et al., 1989; Rogers et al., 1989; Pisulewski et al., 1994; Sloan and Robert, 1995; Armentano et al., 1997), increased both milk yield and milk protein content (Ward et al., 1988; Polan et al., 1991; Fusconi et al., 1995; Thiaucourt, 1996; Pacheco-Rios et al., 1997; Wu-Z et al., 1997), or increased milk fat content (Overton et al., 1996; Piepenbrink et al., 1996; Thiaucourt, 1996).

The inconsistency of responses to RPMet addition might also be attributed to differences in crude protein supply in dry matter of the diet.

According to Rulquin et al. (1993), milk protein responses to postruminal supply of limiting amino acids were much lower on low-protein $(\leq 14 \% \mathrm{CP})$ compared with high-protein rations. The crude protein concentration $(13.7 \%)$ of the diet fed to cows in this experiment was rather low and the supply of protein digestible in the intestine exceeded the requirement only by $1.5 \%$, but this level of crude protein was in agreement with the approach of Schwab et al. (1992a), who suggested that diets with $13.5-14.5 \%$ of crude protein were adequate to ensure milk protein responses to postruminal infusions of methionine and lysine. Rulquin et al. (1995) observed that milk protein content could be dramatically decreased with diets providing less than $2 \%$ of methionine digestible in the intestine, and that a typical grass silage diet complemented with cereals provides only $1.80-1.82 \%$ of methionine digestible in the intestine, and this insufficiency might limit milk production. From the established dose-response relationships, it was concluded that for cows fed on conventional diets, methionine must con- 
tribute 5.3 to $5.6 \%$ of the total essential amino acids in duodenal digesta and $2.5-2.7 \%$ of the total amino acids, respectively, for maximum content and yield of milk protein (Rulquin et al., 1995; Schwab, 1996). The results of our studies suggest that RPMet supplementation in the form of Smartamine ${ }^{\mathrm{TM}}$ affected the postruminal delivery of methionine available for absorption in the intestine, as the content of methionine increased to $24.6 \mathrm{~g} / \mathrm{kg}$ of protein digestible in the intestine, which closely corresponded to a methionine content of $25 \mathrm{~g} / \mathrm{kg}$ of PDI recommended by Rulquin and Vérité (1993).

The improved methionine status of cows in early lactation positively affected not only the milk yield and the synthesis of milk components but influenced the concentration of methionine in the blood plasma. The increase of blood plasma methionine and changes in the concentrations of some other plasma amino acids seem to indicate that the effect of methionine conversion and the pathways of transsulphuration and decarboxylation (McCarthy et al., 1968; Seymour et al., 1990; Pisulewski et al., 1996) were possible. The ranking of limiting amino acids observed in blood plasma of cows fed the diet based on grass silage and grain compound mixture suggests that methionine, isoleucine, lysine and cystine were the first four limiting amino acids, respectively. Increases in concentrations of blood serum methionine and other amino acids as a result of RPMet supplementation were stated by Papas et al. (1984a), Papas et al. (1984b), Rogers et al. (1987), Polan et al. (1991), Overton et al. (1996) and Pisulewski et al. (1996), but these changes in serum amino acid concentrations were not always reflected in a milk production increase. Broderick (1992) suggested that when a limiting amino acid was supplied in excess of the requirement, its accumulation in blood serum could affect the decrease or increase of other amino acids, and the response in blood serum amino acid profiles might vary depending on the basal diet fed.

The criteria of response used for assessing the adequacy of methionine supplementation indicated a significant effect of the utilisation rate and conversion of dietary and added methionine to milk N. However, this high efficiency of $\mathrm{N}$ utilisation in the synthesis of milk proteins was not reflected in the concentration of milk urea. Moreover, the concentration of milk urea was not affected by the increase of blood serum urea observed at Day 56 of lactation. The lack of changes in urea concentration of milk suggests that the supplement of RPMet was used with a high efficiency (Metcalf et al., 1996).

It must be stressed that RPMet was supplied in amounts considered to meet the requirements under the conditions of these studies, because the results showed that RPMet affected not only milk yield and milk protein content and yield but also milk fat content and 4\% FCM yield. The inconsistency of milk fat responses to RPMet supplementation recorded by Donkin et al. (1989), Fusconi et al. (1995), Pisulewski et al. (1996), Armentano et al. (1997), Chilliard and 
Doreau (1997) and Pacheco-Rios (1997) might be caused by differences in the levels and sources of protein supply. RPMet seems to increase milk fat content at a limiting protein supply of $12.5 \%$ crude protein and not at $15.5 \%$ in dry mass of the diet (Chandler et al., 1976).

It is difficult to identify the specific reason for the increased content and yield of milk fat and 4\% FCM in our studies, although several possibilities have been suggested (McCarthy et al., 1968; Chamberlain and Thomas, 1982; Overton et al., 1996; Piepenbrink et al., 1996). According to Seymour et al. (1990), methionine in particular might facilitate the transfer of blood lipids to milk by furnishing methyl groups for synthesis of choline and phosphatidylcholine, which represent an important link between methionine and lipid metabolism in ruminants. McCarthy et al. (1968) and Durand et al. (1992) showed experimentally that methionine might be important for synthesis of lipoproteins and that methionine and lysine facilitated the hepatic secretion of lipoproteins rich in triacylglycerol. Thus methionine contributes to optimising liver function and in particular to preventing accumulation of lipids in the liver.

It is possible that similar mechanism of methionine action in the mammary gland may be responsible for the increase of milk fat content.

The results of these studies confirm the data of Thomas et al. (1980a), Thomas et al. (1980b), Chamberlain and Thomas (1982), Rulquin et al. (1993), Robert et al. (1994) and Rulquin et al. (1995), i.e. that in grass silage based diets supplemented with grain compound mixture methionine is the principal limiting amino acid. The deficiency in dietary methionine can limit milk production in early lactation. Supplementation with rumen protected methionine increases milk yield, milk protein and milk fat content and yield, and improves overall performance of the cow.

\section{References}

AOAC (1984): Association of Official Analytical Chemists: Official Methods of Analysis. $14^{\text {th }}$ ed. Washington, D. C.

Armentano, L. E., Swain, S. M. and Ducharme, G. A. (1993): Lactation response to ruminally protected methionine and lysine at two amounts of ruminally available nitrogen. J. Dairy Sci. 76, 2963-2969.

Armentano, L. E., Bertics, S. J. and Ducharme, G. A. (1997): Response of lactating cows to methionine plus lysine added to high protein diet based on alfalfa and heated soybeans. J. Dairy Sci. 80, 1194-1199.

Backsalary, J. R., Kala, R. and Katulska, K. (1977): Analysis of variance for cross classifications by the method of Bock (in Polish). Rocz. Akad. Roln. Poznań 95, 3-32.

Broderick, G. A. (1992): Relative value of fish meal versus solvent soybean meal for lactating dairy cows fed alfalfa silage as sole forage. J. Dairy Sci. 75, 174-183.

Bruckental, J., Drori, D., Kaim, M., Lehrer, H. and Folman, J. (1989): Effects of source and level of protein on milk yield and reproductive performance of high-producing primiparous and multiparous dairy cows. Anim. Prod. 48, 319-329. 
Budsławski, J. (1979): Analyses of milk and milk products (in Polish). PWRiL Warsaw, pp. 111-112.

Casper, D. P. and Schingoethe, D. J. (1988): Protected methionine supplementation to barley based diet for cows during early lactation. J. Dairy Sci. 71, 164-172.

Chamberlain, D. G. and Thomas, P. C. (1982): Effects of intravenous supplements of L-methionine on milk yield and composition in cows given silage-cereal diets. J. Dairy Res. 49, 25-32.

Chandler, P. T., Brown, C. A., Johnston R. P. Jr., Macleod, G. K., McCarthy, R. D., Moss, B. R., Rakes, A. H. and Satter, L. D. (1976): Protein and methionine hydroxy analog for lactating cows. J. Dairy Sci. 59, 1897-1909.

Chilliard, J. and Doreau, M. (1997): Influence of supplementary fish oil and rumen protected methionine on milk yield and composition in dairy cows. J. Dairy Res. 64, 173-179.

Colin-Schoellen, O., Laurent, F., Vignon, B., Robert, J. C. and Sloan, B. (1995): Interactions of ruminally protected methionine and lysine with protein source or energy level in the diet of cows. J. Dairy Sci. 78, 2807-2818.

Donkin, S. S., Varga, G. A., Sweeney, T. F. and Muller, L. D. (1989): Rumen protected methionine and lysine: effects on animal performance, milk protein yield and physiological measures. J. Dairy Sci. 72, 1484-1491.

Durand, D., Chilliard, Y. and Bauchart, D. (1992): Effects of lysine and methionine on in vivo hepatic secretion of VLDL in the high yielding dairy cow. J. Dairy Sci. 75, Suppl. 1, Abstr. 279.

Fusconi, G., Mancini, V., Rossi, F. and Piva, G. (1995): Effect of rumen protected methionine on production and composition of milk (in Italian). Atti-della-Societa-Italiana-di-Buiatria. 27, 73-78.

Guinard, J. and Rulquin, H. (1995): Effects of graded amounts of duodenal infusions of methionine on the mammary uptake of major milk precursors in dairy cows. J. Dairy Sci. 78, 2196-2207.

Huber, J. T., Emery, R. S., Bergen, W. G., Liesman, J. S., Kung, L., Jr., Gardner, R. W. and Checketts, M. (1984): Influences of methionine hydroxy analog on milk and milk fat production, blood serum lipids and plasma amino acids. J. Dairy Sci. 67, 2525-2531.

Illg, D. J., Sommerfeldt, L. and Schingoethe, D. J. (1987): Lactational and systemic responses to the supplementation of protected methionine in soyabean meal diets. J. Dairy Sci. 70, 620-629.

Jarrige, R. (1989): Ruminant Nutrition: Recommended Allowances and Feed Tables (in Polish). Omnitech Press, Warsaw, pp. 79-100.

King, K. J., Huber, J. T., Sadik, M., Bergen, W. G., Grant, A. L. and King, V. L. (1990): Influence of dietary protein sources on the amino acid profiles available for digestion and metabolism in lactating cows. J. Dairy Sci. 73, 3208-3216.

Lundquist, R. G., Otterby, D. E. and Linn, J. G. (1985): Influence of three concentrations of DL methionine or methionine hydroxy analog on milk yield and milk composition. J. Dairy Sci. 68, 3350-3354.

McCarthy, R. D., Porter, G. A. and Griel, L. C. Jr. (1968): Bovine ketosis and depressed fat test in milk: a problem of methionine metabolism and serum lipoprotein aberration. J. Dairy Sci. 51, 459-462.

McCarthy, R. D., Jr., Klusmeyer, T. H., Vicini, J. L. and Clark, J. H. (1989): Effects of source of protein and carbohydrate on ruminal fermentation and passage of nutrients to the small intestine of lactating cows. J. Dairy Sci. 72, 2002-2016.

Metcalf, J. A., Wray-Cahen, D., Chettle, E. E., Sutton, J. D., Beever, D. E., Crompton, L. A., MacRae, J. C., Bequette, B. J. and Backwell, F. R. C. (1996): The effect of dietary crude protein as protected soyabean meal on mammary metabolism in the lactating dairy cow. J. Dairy Sci. 79, 603-611.

Overton, T. R., La Count, D. W., Cicela, T. M. and Clark, J. H. (1996): Evaluation of a ruminally protected methionine product for lactating dairy cows. J. Dairy Sci. 79, 631-638. 
Pacheco-Rios, D., McNabb, W. C., Hill, J. P., Barry, T. N., Mackenzie D. D. S. and Rios, D. P. (1997): The effects of methionine supply upon milk composition and production of dairy cows in mid-lactation. Proc. New Zealand Soc. Anim. Prod. 57, 147-152.

Papas, A. M., Suiffen, C. J. and Muscato, T. V. (1984a): Effectiveness of rumen protected methionine for delivering postruminally in dairy cows. J. Dairy Sci. 67, 545-552.

Papas, A. M., Vicini, J. L., Clark, J. H. and Peirce-Sandner, S. (1984b): Effect of rumen protected methionine on plasma free amino acids and production by dairy cows. J. Nutr. 114, 2221-2227.

Patterson, J. A. and Kung, L., Jr. (1988): Metabolism of DL methionine and methionine analogs by rumen microorganisms. J. Dairy Sci. 71, 3292-3301.

Piepenbrink, M. S., Overton, T. R. and Clark, J. H. (1996): Response of cows fed a low crude protein diet to ruminally protected methionine and lysine. J. Dairy Sci. 79, 1638-1646.

Pisulewski, P. M., Rulquin, H. and Vérité, R. (1994): The effect of increasing postruminal methionine supply on lactational responses in dairy cows. Ann. Zootech. 43, Suppl., p. 244.

Pisulewski, P. M., Rulquin, H., Peyraud, J. L. and Vérité, R. (1996): Lactational and systemic responses of dairy cows to postruminal infusions of increasing amounts of methionine. J. Dairy Sci. 79, 1781-1791.

Polan, C. E., Cummins, K. A., Sniffen, C. J., Muscato, T. V., Vicini, J. L., Crooker, B. A., Clark, J. H., Johnson, D. G., Otterby, D. E., Guillaume, B., Muller, L. D., Varga, R. A., Murray, R. A. and Peirce-Sandner, S. B. (1991): Responses of dairy cows to supplemental rumen protected forms of methionine and lysine. J. Dairy Sci. 74, 2997-3013.

Robert, J. C., Sloan, B. K. and Denis, C. (1994): The effect of protected amino acid supplementation on the performance of dairy cows receiving grass silage plus soybean meal. Anim. Prod. 58, 437. (Abstr).

Rogers, G. L., Bryant, A. M. and McLeay, L. M. (1979): Silage and dairy cow production. III. Abomasal infusions of casein, methionine and glucose, and milk yield and composition. New Zeal. J. Agric. Res. 22, 533-541.

Rogers, J. A., Krishnamoorthy, U. and Sniffen, C. J. (1987): Plasma amino acids and milk protein production by cows fed rumen protected methionine and lysine. J. Dairy Sci. 70, 789-798.

Rogers, J. A., Peirce-Sandner, S. B., Papas, A. M., Polan, C. E., Sniffen, C. J., Muscato, T. V., Staples, C. R. and Clark, J. H. (1989): Production responses of dairy cows fed various amounts of rumen protected methionine and lysine. J. Dairy Sci. 72, 1800-1817.

Rulquin, H., Pisulewski, P. M., Vérité, R. and Guinard, J. (1993): Milk production and composition as a function of postruminal lysine and methionine supply: a nutrient-response approach. Livestock Prod. Sci. 37, 69-90.

Rulquin, H. and Vérité, R. (1993): Amino acids nutrition of dairy cows: productive effects and animal requirements. In: Garnsworthy, P.C. and Cole, D. Y. A. (eds) Recent Advances in Animal Nutrition. Nottingham University Press, Nottingham, pp. 55-77.

Rulquin, H., Vérité, R., Guinard, G. and Pisulewski, P. M. (1995): Dairy cows requirements for amino acids. In: Center for Food and Animal Research (ed.) Animal Science Research and Development. Agriculture and Agri-Food. Ottawa, Canada, pp. 143-155.

Ryś, R. (ed.) (1985): Feeding Norms for Animals (in Polish). PWRiL, Warsaw, pp. 216-218.

Schwab, C. G., Bozak, C. K. and Whitehouse, N. L. (1992a): Amino acid limitation and flow to duodenum at four stages of lactation. 1. Sequence of lysine and methionine limitation. J. Dairy Sci. 75, 3486-3502.

Schwab, C. G., Bozak, C. K., Whitehouse, N. L. and Olson, V. M. (1992b): Amino acid limitation and flow to the duodenum at four stages of lactation. 2. Extent of lysine limitation. J. Dairy Sci. 75, 3503-3518.

Schwab, C. G. (1996): Rumen protected amino acids for dairy cattle: progress towards determining lysine and methionine requirements. Anim. Feed Sci. and Techn. 59, 87-101. 
Seymour, W. M., Polan, C. E. and Herbein, J. H. (1990): Effects of dietary protein degradability and casein or amino acid infusions on production and plasma amino acids in dairy cows. J. Dairy Sci. 73, 735-748.

Skulmowski, J. (1974): Methods of estimation of fodder components and qualities (in Polish). PWRiL, Warsaw, pp. 15-25.

Sloan, B. K. and Robert, J. C. (1995): Investigation into the limitations in dietary methionine for dairy cows fed a maize silage plus soybean meal based rations. J. Dairy Sci. 78, Suppl. 1, 226. (Abstr.)

Thiaucourt, L. (1996): Use of protected methionine in dairy production (in French). Bulletin-desG.T.V. 2, 45-52.

Thomas, P. C., Chamberlain, D. G., Kelly, N. C. and Wait, M. K. (1980a): The nutritive value of silages. Digestion of nitrogenous constituents in sheep receiving diets of grass silage and grass silage and barley. Brit. J. Nutr. 43, 469-479.

Thomas, P. C., Kelly, N. C., Chamberlain, D. G. and Chalmers, J. S. (1980b): Some aspects of energy and protein utilization in ruminants given silage diets. In: Mount, L. E. (ed.) Energy Metabolism. $8^{\text {th }}$ Symposium, Cambridge, 1979. Butterworths, London, pp. 357-362.

Van Hellemond, K. K. and Sprietsma, J. E. (1977): Effect of supplementation of methionine and methionine hydroxy analog on milk yield, milk fat and milk protein. Z. Tierphysiol. Tierernährg. Futtermittelkd. 39, 109-115.

Van Soest, P. J. and Wine, R. H. (1967): Use of detergents in the analysis of fibrous feeds. IV. Determination of plant cell-wall constituents. J. Assoc. Off. Anal. Chem. 50, 50-55.

Ward, N. E., Wicker, D. L., Koch, F. and Gunther, K. D. (1988): Influence of protected DL methionine $\left(\right.$ Mepron $\left.^{\circledR}\right)$ on the production of dairy cows and heifers. J. Dairy Sci. 71, Suppl. 1, 160. (Abstr.)

Wu-Z, Fisher, R. J., Polan, E. E. and Schwab, C. G. (1997): Lactational performance of cows fed low or high ruminally undegradable protein prepartum and supplemental methionine and lysine postpartum. J. Dairy Sci. 80, 722-729. 
Acta Veterinaria Hungarica 47 (2), pp. 191-206 (1999)

0236-6290/99/\$ 5.00 @ 1999 Akadémiai Kiadó, Budapest 